\title{
A LIMITAÇÃO DO ÉLENCHOS E SUA IMPLICAÇÃO NA DEFESA DE SÓCRATES CONFORME A APOLOGIA DE PLATÃO
}

Fábio Amorim de Matos Júnior

\begin{abstract}
RESUMO
Consoante exposto por Platão na Apologia, Sócrates apresenta sua defesa a partir de duas perspectivas distintas: uma dirigida às mais antigas calúnias (diabolaí) - que lhe foram outrora infligidas - e outra à acusação (grafh) posta por Meleto. Posteriormente, depois de realizada a defesa e consolidada a condenação, o filósofo conferirá o resultado do processo (agwn) àquelas primeiras acusações, pois, conforme acredita, foi absolvido no que tange às impostas por Meleto (Apologia, $16 \mathrm{a}-\mathrm{b}$ ). Portanto, a partir desse quadro, compete à tradição crítica determinar: por qual motivo Sócrates atribui sua condenação às antigas diabo laí; e, sobretudo, se ele não desejou ou não pôde refutar aquelas acusações. $O$ presente artigo almeja oferecer algumas indicações à guisa de resposta para essas questões e demonstrar em que medida os limites do método (elegcoç) do filósofo inviabiliza sua defesa, isto é, apontar-se-á como Platão vincula a condenação do mestre às limitações do e legcoç.
\end{abstract}

PALAVRAS-CHAVE: Apologia de Sócrates. Elenchos. Erótesis. Judiciário grego. Contexto dramático.

ABSTRACT

According to what Plato exposed in the Apology, Socrates presents

Doutorando em Filosofia pela Universidade Estadual de Campinas (UNICAMP). 
his defense through two distinct perspectives: the first delivered to the oldest calumnies (diabolaí) - which were inflicted upon him in the past - and the second delivered to the accusation (grafh) given by Meletus. Later, after the defense was made and the condemnation was consolidated, the philosopher will adjudicate the result of the process (agwn) to those first accusations, because, as he believes, he was considered not guilty in relation to the accusations put forth by Meletus (Apology, $16 \mathrm{a}-\mathrm{b}$ ). Therefore, from this scenario, it belongs to the competence of the critical tradition to determine: for what reason Socrates attributes his own condemnation to the ancient diabo laí? Above all, whether he did not want to or could not refute those accusations. The present paper aims at offering some indications as answer to these questions and at demonstrating in what measure the limits of the philosopher's method of refutation (e legcoç) makes turn unviable his own defense impossible; that is to say, it will be shown how Plato links his master's condemnation to the limitations of the elegcoç.

KEYWORDS: Apology of Socrates. Elenchos. Erótesis. Judiciary greek. Dramatic context.

\section{O sistema jurídico na Atenas de Sócrates}

O aparelho jurídico ateniense, fruto de um sistema democrático que se fundamentava na soberania popular, concedia a qualquer cidadão a prerrogativa de apresentar uma queixa a ser julgada pela Heliéia. Todas queixas eram caracterizadas como causas públicas (grafaí) ou privadas (dikaí). As primeiras poderiam ser apresentadas por quem quisesse, ao passo que as últimas reservavam-se para os diretamente atingidos ou seus representantes. Em primeira instância, a denúncia era dirigida aos magistrados, isto é, ao Arconte-rei que era encarregado de analisar se o caso fazia jus ao estabelecimento de um processo (agwn). Para tanto, o magistrado convocava as partes envolvidas e apresentava os termos

Educ. e Filos., Uberlândia, v. 21, n. 42, p. 119-153, jul./dez. 2007. 
da acusação ao acusado, o qual deveria ou reconhecer a queixa ou opor-se a ela, terminando a seção com um sermão mútuo (antwmosía) dirigido às partes. Quando o acusado não reconhecia a acusação, constituía-se um tribunal e marcava-se um dia para o julgamento. Todos os heliastas eram convocados a comparecerem e, dentre os presentes, era realizado um sorteio para definir os que participariam da seção do dia. Assim, na data marcada para o julgamento, estando as duas partes presentes, iniciava-se o agwn. Primeiramente, competia a um escrivão a leitura da denúncia e da lei - caso existisse - que o réu era acusado de violar; posteriormente, era concedido às partes, cada qual por sua vez, o direito de apresentar suas argumentações.

Uma vez findos os discursos, procedia-se à votação e ao estabelecimento da pena. Faz-se mister salientar que uma característica do judiciário grego manifesta-se na ausência de "advogados", isto é, tanto a acusação quanto a defesa deveriam ser realizadas pelo denunciante e pelo réu, respectivamente, e cada qual por sua vez. Por esse motivo, na maioria dos casos, procediase à leitura de discursos anteriormente preparados por logógrafos ${ }^{1}$, os quais visavam suprir as carências retóricas dos envolvidos, também como garantir uma maior objetividade nos resultados uma vez que esses dominavam as técnicas apropriadas ao convencimento do tribunal.

Sabe-se que a grafh encaminhada por Meleto ao Arconte-Rei contra Sócrates constitui, no sistema jurídico ateniense, o que se denominava por agwn timhtóç - isto é, um processo cuja pena não se encontrava prevista por lei. Destarte, cabia ao acusador, no momento em que registrava a queixa, indicar uma possível

\footnotetext{
1 Embora se atribua a esses homens a função de "advogados de papel” , é necessário estar ciente das diferenças que a relação anacrônica apresenta, uma vez que os "logógrafos" não dispunham de recursos como o interrogatório do réu, o exame dos testemunhos ou a referência a pontos aludidos pelo adversário, etc. Isso se dava porque sua argumentação era preparada anteriormente ao curso do processo. Saliente-se ainda que a existência desses profissionais exerceu grande influência no sistema judiciário grego; mas, embora corrente, tal prática, legalmente, não podia ser remunerada sob pena de perseguição.
} 
penalidade a ser ministrada ao réu. Logo, uma vez que o acusado não obtivesse os sufrágios necessários para sua absolvição - pois, caso os obtivesse, findava a queixa posta contra ele e aplicava-se uma multa ao acusador -, os heliastas realizavam nova votação, no intuito de estipular a punição a ser cumprida. Assim, optavase entre a pena proposta pelo acusador e a contra-pena (antitímhsiç) designada pelo acusado. No caso de Sócrates, a punição encaminhada por Meleto foi a sentença de morte; ao passo que o filósofo estipula - em primeira instância - como punição ser alimentado no Pritaneo ${ }^{2}$, o que é, posteriormente, substituído por uma multa no valor de uma mina - a qual, uma vez avultada pelos amigos de Sócrates, se fixa no montante de trinta. Ora, se Sócrates, na primeira votação, não tinha sido absolvido pelo número irrisório de trinta votos - quantia pequena, uma vez que, possivelmente, o julgamento tenha tido por volta de quinhentos heliastas - provavelmente, na segunda, a diferença tenha sido mais gritante, na medida em que a atitude socrática deve ter se apresentado irônica e insolente aos olhos dos juízes.

Assim, no intuito de promover e reproduzir a defesa do mestre concorde o roteiro do julgamento, seria mais ou menos este o percurso traçado por Platão na redação da Apologia: primeiramente, entre $17 \mathrm{a}-35 \mathrm{~d}$, apresenta o autor o discurso que teria sido proferido por Sócrates na intenção de sua defesa - após o que ocorre a primeira votação -; entre 36a-38b, situa-se a antitímhsiç proposta pelo filósofo, em virtude de tratar-se de um agwn timhtóç - momento em que se realiza a segunda votação ; e, por fim, entre 38c até o final do texto, encontrar-se-ia o discurso

\footnotetext{
2 Segundo Brisson (1997, p. 42), era comum que o acusador pedisse uma pena acima da que realmente estimava necessária, no intuito de obrigar o acusado a ser generoso em sua contra proposta (antitímhsiç) - uma vez que não se havia possibilidade da aplicação de uma terceira opção, ou seja, os juízes votavam a favor de uma ou outra das sentenças propostas. Assim, quando Meleto propôs a pena de morte, não esperava ele obter tal resultado, mas, provavelmente, desejava o exílio de Sócrates - o que era uma punição apropriada para a gravidade do caso.
}

Educ. e Filos., Uberlândia, v. 21, n. 42, p. 119-153, jul./dez. 2007. 
proferido pelo réu após a condenação à morte. Muito se tem discutido sobre a autenticidade histórica dessa última parte da Apologia, isto é, sobre a veracidade desse discurso de Sócrates e sua relação com o processo. A contenda toma corpo na medida em que, feito o anúncio do resultado, chegava o processo ao seu fim, após o que se realizava, no campo, o pagamento dos magistrados. Ao mesmo tempo, como nenhuma fonte indica que após a sentença a palavra fosse novamente concedida ao réu, discute-se a respeito dessa parte do texto: teria ela sido pronunciada por Sócrates durante o processo ou à parte somente a seus amigos? Ao que, talvez, possa ser acrescido uma terceira possibilidade: se teria sido um aumento de Platão à história, no intuito de fortalecer seu propósito apologético. Todavia, independentemente da verossimilhança de 38c-20a com os fatos, a Apologia de Sócrates é considerada, pela tradição crítica, um exemplar verídico da situação jurídica ateniense; sobretudo no que tange à prática de um procedimento - embora enunciado por Lísias XII 23-25, XIII 30 e XXII 5 - incomum ao tribunal, a saber: a interrogação direta entre os oponentes do agwn, isto é, a erwthsiç.

Destarte, faz-se conveniente, posteriormente a esse breve sobrevôo sobre o judiciário ateniense ${ }^{3}$, mergulhar no texto da Apologia, com o intuito de apresentar as argumentações que visam sustentar a hipótese levantada pelo presente estudo, a saber: Sócrates, tal qual o retrata Platão, encontra-se incapacitado de realizar a defesa de parte das acusações apresentadas na Apologia, mais precisamente, das mais antigas, sendo que tal impossibilidade, acredita este texto, faz-se oriunda de limitações inerentes ao seu método filosófico.

3 Eis os textos que muito contribuíram para a precedente caracterização do judiciário grego. De Claude Mossé (1982; 1990; e 1995); a introdução da tradução da Apologia feita por Luc Brisson (1997); e, por fim, o artigo de Louis-André Dorion (1990). Evidentemente há uma gama de livros sobre o assunto, de modo que, para uma leitura aprofundada sobre o tema, queira recorrer o leitor à bibliografia das obras citadas. 


\section{A defesa de Sócrates na Apologia de Platão}

\subsection{As mais antigas acusações}

Sabe-se que Sócrates enumera em sua defesa duas classes de acusações (kathgoríai) que lhe são atribuídas (Apol. 18a): as mais antigas (prwta kathgorhména), advindas de boatos correntes na pólis sobre sua pessoa e de calúnias expressas por Aristófanes em sua comédia As Nuvens; e as mais recentes, impostas pelos do círculo de Meleto. Nas primeiras, as mais antigas, identifica o filósofo um maior grau de temeridade a ser observado, apesar do temor que dedica ao processo em questão. Tal temeridade deve-se ao fato de que aquelas acusações foram realizadas pelos que cuidaram da educação da maioria dos presentes no julgamento, com a agravante de que foram apresentadas quando estavam os do júri ainda em tenra idade - isto é, quando perpassavam pela etapa mais inapta à crítica. Todavia, parece que o maior problema posto por essas acusações encontra-se no fato de não se poder delimitar, seja em nome, seja em número, os acusadores; o que implica, diretamente, na impossibilidade de uma refutação (elegcoç) em juízo. Eis como apresenta Sócrates as dificuldades impostas por essas mais velhas calúnias:

Depois, essas acusações são numerosas e vêm acusando há muito tempo; mais ainda, falavam convosco na idade em que mais crédulos podíeis ser, quando alguns de vós éreis crianças ou rapazes, e a acusação era feita a inteira revelia, sem defensor algum. De tudo, o que tem menos sentido é não se poderem dizer nem saber os seus nomes, salvo quando se trata, porventura, de um autor de comédias (Apol. 18c-d) $)^{4}$.

4 Trata-se de Aristófanes em sua peça As Nuvens. A apresentação cômica da figura de Sócrates nessa obra revela, concorde Apol. 33d, o que se poderia denominar de acusação do senso comum a todo filósofo, a saber: o estudo fisiológico, o manejo dos dissoì lógoi e o ateísmo. Veja-se Apol. 18b-c. Todas as citações da Apologia de Sócrates, salvo indicação em contrário, serão extraídas da tradução de Jaime Bruna (PLATÃO, 1972).

Educ. e Filos., Uberlândia, v. 21, n. 42, p. 119-153, jul./dez. 2007. 
Assim, uma vez classificadas as calúnias, estabelece-se o cronograma para a defesa, o qual perpassa, primeiramente, pelas acusações mais antigas, culminando com as acusações impostas por Meleto. Contudo, mesmo antes de apresentar sua defesa, não escapa ao filósofo a grande dificuldade (calepon) de conseguir refutar, em prazo tão curto, acusações de tão grande monta, semeadas por tantos anos, de modo que, por ser tão árdua, a tarefa já parece lhe anunciar o modo como culminará:

Bem, Atenienses, é mister que apresente minha defesa, que empreenda delir em vós os efeitos dessa calúnia, a que destes guarida por tantos anos, e isso em prazo tão curto. Eu quisera que assim acontecesse, para o meu e para o vosso bem, e que lograsse êxito a minha defesa; considero, porém, a empresa difícil e não tenho a mínima ilusão a esse respeito. Seja como for, que tomem as coisas o rumo que aprouver ao deus ${ }^{5}$, mas cumpre obedecer à lei e apresentar a defesa (Apol., 18e-19a).

O núcleo das acusações mais antigas consiste, como já aludido, basicamente em três tópicos: um que confere a Sócrates um saber fisiológico; outro que lhe toma como um retórico dos dissoì Iógoi; e um último que lhe atribui um procedimento corruptivo. Contudo, um outro ponto se soma às três aleivosias, na medida em que se acredita que os investigadores de tais matérias não crêem nas divindades (Apol., 18c); de modo que implícita naquelas acusações figura também a que prega um Sócrates ateu. Eis como rezam os termos da acusação: "Sócrates é réu de pesquisar indiretamente o

5 Faz-se de bom grado notar que, durante todo o texto da Apologia, Platão insiste em salientar a piedade socrática, apresentando de todas as maneiras possíveis o elo entre o mestre e a divindade. O que reforça a hipótese que confere papel ímpar à função exercida pela construção dramática dos diálogos do autor, na medida em que uma das acusações que levam Sócrates à cicuta coincide justamente na tributação de impiedade. Nesse ínterim, Platão não somente fecha o julgamento com a recorrência à divindade (Apol., 42a), como apresenta o mestre, no momento em que se lhe fecham as cortinas da vida, a emitir como pedido derradeiro o cumprimento de um dever religioso (Fédon, 118a). 
que há sob a terra e nos céus, de fazer que prevaleça a razão mais fraca e de ensinar aos outros o mesmo comportamento" (Apol., 19c).

Entrementes, o procedimento utilizado por Sócrates para tentar refutar essas calúnias não se faz in totum convincente. $\mathrm{Na}$ verdade, sua argumentação direta limita-se a enunciar que desconhece semelhantes práticas - refere-se aos dois primeiros pontos da acusação -, invocando os expectadores como testemunhas (martúreç), isto é, inquirindo-os quanto a algum dentre eles já o ter escutado discorrer sobre tais matérias. Porém, uma vez que não era plausível a procedência da acusação, e o público não se manifesta, pretende Sócrates responder de modo geral a toda a argumentação que se lhe apresente: "Assim, ficareis sabendo que é do mesmo estofo tudo o mais que por aí se fala de mim" (Apol., 19d). Nisso consiste toda a argumentação direta de defesa às primeiras calúnias, justamente as que se apresentam como as mais fortes e que o levarão à morte. Toda a argumentação subseqüente faz-se por vias não diretas. Na seqüência (19d-20c), utiliza-se o filósofo de sua tão aclamada ironia - e aqui pode ser encontrado um exemplo de tentativa de refutação histórica - para evidenciar alguns aspectos de distinção entre seus hábitos e o procedimento sofístico, sobretudo no que tange à prática de se cobrar por lições, que teriam a pretensão de poderem tornar melhores os homens. Nesse ínterim, afirma Sócrates que se "orgulharia e ensoberbeceria de ter a mesma ciência" (Apol., 20c), embora sobre ela nada conheça.

Uma outra presença da argumentação histórica pode ser verificada ainda na parte do texto dedicada às primeiras acusações (Apol., 20c-24b), quando Sócrates procura evidenciar ao público as origens de tais calúnias. Nesse sentido, colocando uma questão retórica, que diz respeito à sua ocupação, identifica o filósofo que a procedência de tal reputação caluniosa lhe é advinda da desconfiança em face de seu hábito pouco fora do comum. Isto é, deve-se à prática de sua ciência, que, distintamente do conhecimento fisiológico, verifica-se no conhecimento humano. Essa ciência, segundo Sócrates, encontra-se arraigada ao desejo

Educ. e Filos., Uberlândia, v. 21, n. 42, p. 119-153, jul./dez. 2007. 
divino, na medida em que sua origem situa-se a partir de uma resposta dada pelo Oráculo de Delfos a Querefonte - pessoa amiga do povo, do partido e tenaz em seus procedimentos (Apol., 21a), isto é, um cidadão reconhecidamente distinto em relação aos seus pares. O fato é que o oráculo haveria atestado a Querefonte ser Sócrates o mais sábio (sofwtaton) dentre os homens, e como não tinha o filósofo semelhante opinião, tomou ele a resolução de investigar qual seria o sentido oculto no oráculo. Para tanto, se pôs a examinar as pessoas tidas como as mais sábias - políticos, poetas e artífices -, quando descobriu carecerem todas elas de uma real sabedoria: na medida em que criam ser sábios (sofóç) naquilo que não o eram. Nesse sentido, aceita Sócrates ser mais sábio do que eles:

(...) é bem provável que nenhum de nós saiba nada de bom, mas ele [um político] supõe saber alguma coisa e não sabe, enquanto eu, se não sei, tampouco suponho saber. Parece que sou um nadinha mais sábio do que ele exatamente em não supor que saiba o que não sei (Apol., 21d-e).

Destarte, aqueles por ele refutados, não se tratando de interlocutores ideais - como os do Laques, por exemplo -, voltavamse odiosamente, não contra si mesmos, mas contra o refutador dirigindo-lhe toda uma gama de animosidades. Logo, "tantas inimizades, tão acirradas e maléficas, que deram nascimento a tantas calúnias" se devem a essa investigação de procedência divina. Devido à importância do último ponto aludido, mister é que se faça um parêntese na argumentação; o que cumpre o próximo parágrafo.

Essa passagem 20c-23a, referente ao oráculo de Delfos, muito tem exaltado os ânimos da interpretação crítica, seja em virtude de seu significado ou das conseqüências que dela desprendem-se. De fato, Platão vincula o procedimento filosófico de Sócrates à resposta do oráculo, isto é, a "[...] Apologia faz do recito do oráculo de Delfos a origem da vida filosófica de Sócrates" (DORION, 1990, p. 333). Por outro lado, o procedimento de Sócrates, posteriormente 
ao oráculo, é nada menos do que uma tentativa de refutar a resposta do deus. Eis as palavras de Sócrates:

[...] por fim, muito contra meu gosto, decidi-me por uma investigação que passo a expor. Fui ter com um dos que passam por sábios, porquanto, se havia lugar, era ali que, para rebater o oráculo (e légxwn tò manteîon), mostraria ao deus: "eis aqui um mais sábio do que eu, quando tu disseste que eu o era" (Apol., 21b-c).

Concorde Dorion (1990, p. 333), coube a Strycker e West a observação de que o oráculo constitui o ponto de partida do procedimento socrático, de modo que, não fosse a resposta dada a Querofonte, Sócrates nunca teria empreendido sua atividade. Todavia, pretende Dorion adentrar mais profundamente nas conseqüências da passagem e retirar todas as implicações possíveis. Firme nesse propósito, alude o autor que, nos moldes indicados pelo texto platônico, tudo passa como se Sócrates nunca houvesse questionado ninguém, como se sua prática refutativa houvesse surgido espontaneamente - desprovida de qualquer influência anterior - unicamente para dar cabo da resposta emitida pelo oráculo. Realmente, semelhante posição manifesta-se um tanto quanto improvável, na medida em que o renome gozado por Sócrates - ao menos o legado pela tradição - repousa essencialmente a partir da prática por ele preconizada. Ora, assim sendo, quais outros caracteres poderiam lhe conferir algum renome perante seus cidadãos? Ou seja, se não fosse sua Filosofia, qual motivo levaria Querofonte a interpelar o oráculo quanto a ser Sócrates, dentre todos os homens, sofwtatoç? Entrementes, embora pareça Dorion (1990, p. 334) ter acertado muito bem na afirmativa de que:

O episódio do oráculo de Delfos assemelha-se muito a um recito mítico de origem, quer dizer, a um recito onde Platão atesta uma origem divina a uma prática que, mesmo que tenha sido sobretudo utilizada por Sócrates, devia certamente inspirar-se em práticas anteriores (...);

Educ. e Filos., Uberlândia, v. 21, n. 42, p. 119-153, jul./dez. 2007. 
o desenvolvimento de sua argumentação apresenta-se um tanto quanto forçado, uma vez que para corroborar sua hipótese segundo a qual o método socrático origina-se na prática judiciária ateniense - tenta o comentador encontrar, nos móbeis que moveram Platão a apresentar semelhante vinculação (da atividade de Sócrates com Delfos), uma estratégia do autor dos diálogos para mascarar as origens do método socrático, isto é, uma tentativa de apagar a dívida existente entre o procedimento do mestre com a prática judiciária e, assim, dar-lhe uma origem totalmente inata ao filósofo. Ora, embora concordante com a hipótese de vinculação entre o método socrático e a prática dos tribunais, o presente texto inclina-se a uma hipótese explicativa bem menos artificial para o oráculo de Delfos, a saber: Platão, ao promover uma origem divina para o procedimento socrático, estaria simplesmente a reforçar a inocência do mestre, a explicitar o absurdo de acusar-se um homem de impiedade religiosa justamente por uma prática que encontra nesse preceito suas origens, isto é, visualiza-se um intuito apologético nessa origem mítica do procedimento de Sócrates, quer dizer, uma espécie de dramatização quanto a sua origem que visasse reabilitar o mestre injustiçado. Bem, após esse breve parênteses, talvez esteja em tempo de retornar ao desenvolvimento natural da argumentação exposta na Apologia, pois, nessa altura, Sócrates talvez impaciente - já apresente suas últimas argumentações para as antigas acusações.

Assim, após estabelecer o liame entre sua ocupação e a vontade divina, adverte o filósofo sobre a origem das calúnias que envolvem sua persona. Consoante ele, as mesmas provêm do fato de muitos dos jovens que o acompanham em suas investigações - geralmente os das famílias mais ricas, por serem os que dispõem de maior tempo livre (Apol., 23c) - por vezes porem-se a imitá-lo, descobrindo desse modo muitas pessoas "[...] que supõem saber alguma coisa, mas que pouco sabem, quiçá nada" (Apol., 23c). Desse hábito decorre a exasperação caluniosa dos examinados em torno do nome de Sócrates. São essas pessoas que, por não se voltarem contra si próprios - ignorando o bem que a refutação constitui para elas -, “[...] propalam que existe um tal Sócrates, um grande miserável, 
que corrompe a mocidade" (Apol., 23c-d). Assim, finda-se a parte da defesa apresentada às primeiras e mais terríveis acusações.

Contudo, embora o filósofo frise que não precisa dizer mais nada para sua defesa no tocante àquelas acusações (24b), poderse-ia perguntar se sua argumentação faz-se suficiente. Ou seja, Sócrates conseguiu refutar de modo satisfatório aquelas primeiras acusações? A hipótese levantada pelo texto presente, como já é de conhecimento do leitor, reza que Sócrates não as refuta, ou ao menos não de modo satisfatório. Ora, em sua única argumentação direta às acusações, Sócrates apresenta uma tentativa de indução que não pode ser tida como satisfatória para qualquer espécie de defesa. Dizer que não possui relação com determinado assunto e tentar prová-lo a partir do testemunho alheio não é o que se espera do homem que durante toda vida dedicou-se a demonstrar aos outros - inclusive àqueles de argumentação mais elaborada - as contradições contidas em seus raciocínios, e que para tal utilizouse de recursos metodológicos bem complexos, a ponto de muitas vezes o interlocutor não perceber a contradição, que já se apresentava iminente em seu discurso, a não ser no momento em que lhe era anunciada. O que faz, após a tentativa de indução (Apol., 19d), não consiste em nada mais do que estabelecer alguns paralelos distintivos entre ele e os sofistas e enumerar as causas originárias para a reputação que o fez alvo de semelhantes acusações. $O$ primeiro procedimento dirige-se à parte da acusação que lhe credita o manejo dos argumentos, e o outro procura dar cabo das outras três acusações - fisiologia, corrupção e ateísmo. Mas, será que ao ressaltar ironicamente que não possui a pretensão do conhecimento sofístico e que não cobra por seus ensinamentos - os quais, para ser mais exato com sua modéstia, nem se realizam -, consegue Sócrates imprimir no público ouvinte o caráter de suas pesquisas? Isto é, será que ele consegue demonstrar satisfatoriamente, a um público não especializado - que não era em sua totalidade os de seu círculo de relacionamento -, que sua ciência apresenta preceitos que visam à verdade e não à aparência discursiva? O presente texto acredita que não! Principalmente se levado em consideração que, muito provavelmente, os

Educ. e Filos., Uberlândia, v. 21, n. 42, p. 119-153, jul./dez. 2007. 
contemporâneos de Sócrates não deviam ter muito bem delimitada a linha que distingue o procedimento sofístico do filosófico - o que somente far-se-á preciso a partir do legado de Platão e Aristóteles. Por outro lado, mesmo que possa ter conseguido demonstrar de que modo se originaram semelhantes calúnias - que constitui, como visto, acusação comum a quase todos os filósofos -, o próprio Sócrates reconhece, ao cabo de sua defesa, a infertilidade de suas argumentações perante os presentes: "Dessarte, como dizia ao começar, eu ficaria surpreso se lograsse, em tão curto prazo $^{6}$, delir em vós os efeitos dessa calúnia assim avolumada" (Apol., 24a). Ou seja, como poderia ele se defender de forma satisfatória, em tempo tão curto, de acusações que se encontravam tão arraigadas devido à propagação que se disseminara por muitos anos? Por tais razões, crê-se que a argumentação de Sócrates perante as primeiras aleivosias não se faz suficiente nem para convencer os presentes de sua inocência, nem para refutá-las de forma satisfatória. Caso se apresentasse o contrário, isto é, caso se admitisse que as argumentações foram suficientes, ter-se-ia necessariamente que considerar como irônicos alguns trechos do diálogo ${ }^{7}$ referentes ao reconhecimento de Sócrates em face da ineficácia de sua defesa, como atesta o filósofo:

(...) mas é que estou convencido de que não faço mal a ninguém por querer, mas não consigo convencer-vos disso. É que conversamos durante pouco tempo; se fosse norma entre vós, como em outros povos, não decidir um processo

${ }^{6}$ Note-se a menção ao fator temporal da defesa apresentada. Mais uma vez conota Platão uma crítica ao regime democrático - o que será explicitado mais detalhadamente por Sócrates em (Apol., 37a-b). Além dessas passagens, Brisson (1997, p. 156) aponta também as seguintes recorrências ao tema: para a impossibilidade de se alçar à verdade durante o tribunal, devido ao exíguo tempo, Górgias (455a), Teeteto (201a), Leis (766e).

7 Além da passagem acima citada (Apol., 24a), pode-se mencionar também este outro trecho: "[...] talvez imagineis, senhores, que me perdi por falta de discursos com que vos poderia convencer, se na minha opinião se devesse tudo fazer e dizer para escapar à justiça" (Apol., 38d). 
capital num dia só, mas em muitos, suponho que vos teria convencido, infelizmente, não é fácil em tempo exíguo escoimar-se de calúnias tão fortes (Apol., 37a-b).

E na medida em que o trecho citado revela também uma crítica ao sistema jurídico ateniense, fato não incomum em Platão, é mister que não se possa tomá-lo como uma passagem irônica. Logo, ou se admite que Sócrates não refuta satisfatoriamente as acusações antigas, ou se admite que ele acredita não refutá-las, conquanto o tenha feito. Embora não se possa resolver a contenda utilizandose como resposta o fato da condenação, na medida em que a mesma não implica que não tenha ele conseguido refutar o que lhe foi apresentado, pode-se, todavia, pensar que por ter sido Platão quem redigiu o texto, talvez tenha sido essa sua impressão do julgamento - embora a fragilidade dessa argumentação não lhe permita ser tomada como caráter de solução. Nesse caso, faz com que impere a opinião emitida pelo filósofo sobre o assunto, uma vez que dado o caráter assumido pelo personagem "Sócrates" nos diálogos de Platão - nos quais a palavra do mestre sempre se nivela como sinônimo de verdade e sabedoria - e, sobretudo, excluída a impossibilidade de tratar-se de um juízo irônico, é mister creditar como verdadeira a asserção de que as mais antigas acusações não haveriam sido refutadas. Por essas razões, pressupõe-se aqui que Sócrates não consegue refutar de maneira satisfatória as prwta kathgorhména. Porém, o argumento mais forte para firmar semelhante hipótese depende da explicitação do método socrático. Todavia, somente depois de exposto o restante das argumentações da Apologia, explicitar-se-á o referido pressuposto e dar-se-á cabo da argumentação.

\subsection{As acusações constituintes do agwn}

Na seqüência (Apol., 24b-34b), cumpre a Sócrates defender-se das acusações de Meleto, que, embora sejam menos temíveis, são as que o movem ao julgamento presente (agwn). Essas últimas acusações visam a dois fatores fundamentais: a corrupção da

Educ. e Filos., Uberlândia, v. 21, n. 42, p. 119-153, jul./dez. 2007. 
juventude e a instauração de novas divindades. Atestam: "Sócrates é réu de corromper a mocidade e de não crer nos deuses em que o povo crê e sim em outras divindades novas" ${ }^{8}$ (Apol., 24b-c). Nesse ínterim, propõe Sócrates uma contra-acusação a Meleto, declarando-o leviano por trazê-lo a julgamento por assuntos dos quais nunca se ocupou; o que implica necessariamente que não sabe do que fala, ou seja, de que lança acusações à pura revelia. De modo que a argumentação de Sócrates, além de refutação direta ao lógos apresentado, visará a demonstrar que Meleto não se interessa pelos assuntos de que o acusa. Nas palavras de Sócrates:

Diz que sou réu de corromper a mocidade. Mas eu, atenienses, afirmo que Meleto é réu de brincar com assuntos sérios; por leviandade, ele traz a gente à presença dos juízes, fingindose profundamente interessado por questões de que jamais fez o mínimo caso (Apol., 24c-d).

Desta vez, todavia, Sócrates arranja a discussão a sua maneira habitual (Apol., 27b), isto é, submete o acusador ao crivo de seu método característico, de maneira tal que uma a uma vão sendo refutadas as acusações outrora postas. Para refutar o primeiro tópico da acusação, o da corrupção da juventude, Sócrates pergunta a Meleto - já que constitui assunto que lhe toca o interesse - quem são os que tornam melhores os jovens, uma vez que, se ele sabe quem os corrompe - Sócrates -, é natural que saiba também quem os melhora. Ao que o poeta nomeia serem as leis. Sócrates, todavia, não se contenta e pede que aponte dentre os particulares aqueles que conhecem as leis (Apol., 24e). Do que se concluirá que todos os atenienses os tornam melhores, exceto Sócrates, que os corrompe. Uma vez aceita essa premissa, Sócrates, através do

8 Perceba-se que as acusações de Meleto retomam o texto das mais antigas, embora aquelas apresentem um desenvolvimento diferente. Sócrates presume (Apol., 19b) que as calúnias de Meleto originam-se devido ao crédito que este dá às acusações mais antigas, de modo que são as últimas as principais responsáveis pela condenação. 
procedimento "epagógico", alude que com os cavalos, assim como com os outros animais, ocorre exatamente o oposto: uma só pessoa os torna melhores no adestramento, ao passo que a maioria os vicia; de modo que essa "regra geral" teria sua única exceção no caso da corrupção dos jovens. Nesse ponto, já se encontra abalada a tese de Meleto, porém, somente com o retorno ao procedimento silogístico, anteriormente utilizado (quando do estabelecimento da premissa: somente Sócrates é corruptor da juventude), o filósofo dar-se-á por satisfeito. Assim, tendo como pressuposto que o danoso é causador do mal e o prestimoso do bem - ao que seu interlocutor assente -, Sócrates inquire a Meleto entre quais dessas companhias faz-se preferível habitar e se há possibilidade de que alguém deseje para si o mal. Meleto, já constrangido, responde que ninguém pode querer o mal e que é preferível habitar entre prestimosos. Estabelecida essa premissa, Sócrates quer então saber se ele corrompe a juventude por querer ou sem que o queira; ao que Meleto deixa claro ser por vontade própria, isto é, deliberadamente. Situada essa outra premissa, fica fácil a Sócrates demonstrar a contradição entre ambas: pois, se os maus são daninhos a seus próximos e se essa situação não pode ser desejada, então Sócrates não pode corromper a juventude voluntariamente. Caso isso ocorresse, contrariaria a premissa de que ninguém pode desejar por querer o dano para si. Logo, ou Sócrates não corrompe ou, se o faz, não pode sê-lo voluntariamente. Nesses termos, refuta Sócrates o primeiro ponto da acusação.

Ao dar seqüência à defesa, volta-se o filósofo para o segundo ponto: o da instauração de novas divindades. Posto rezarem os termos da acusação que Sócrates não crê nos deuses da pólis, mas em outras divindades, infere o filósofo, então, que não está sendo acusado de ateísmo, pois, se crê - instaurando novas divindades , não pode ser ateu. Meleto não consente nessa última alternativa e diz ser esse o caso de Sócrates. Nesse sentido, a denúncia já patenteia imediatamente sua auto-contradição: pois, se Sócrates não crê nos deuses da cidade, mas em outras divindades, deve necessariamente admitir-se que crê em alguma divindade; mas, se como afirma Meleto, Sócrates é ateu, então, não pode ele ser

Educ. e Filos., Uberlândia, v. 21, n. 42, p. 119-153, jul./dez. 2007. 
responsabilizado pela instauração de crenças em novas divindades. Nas palavras de Sócrates: "Penso que ele [Meleto] se contradiz na denúncia; como se dissesse: 'Sócrates é réu de crer nos deuses em vez de crer nos deuses'" (Apol., 27a). Todavia, para deixar mais patente a contradição, elenca o filósofo uma série de argumentações que visam concluir que não se pode negar existência a determinado ser, ao mesmo tempo em que se afirma a existência do que lhe é correlato, ou seja, não se pode, por exemplo, não crer em cavalos mas acreditar na equitação. Por esse procedimento "epagógico", Sócrates demonstra que a acusação de Meleto não procede, uma vez que, conforme este jurara na acusação, Sócrates ensina a prática de poderes demoníacos (Apol., 26c). Ora, sendo os demônios ou deuses ou filhos de deuses, não pode ele não crer em deuses ao mesmo tempo em que crê em deuses, pois não se pode acreditar em filhos de deuses sem que se creia na existência dos últimos. Desse modo, as acusações impostas por Meleto se fazem in totum refutadas.

Mas, eis que o momento faz-se propício para a apresentação de uma objeção que foi feita ao autor deste texto ${ }^{9}$. Apresentava ela mais ou menos estes termos: "[...] mas, haverá Sócrates realmente refutado a acusação de impiedade? Isto é, na medida em que a grafh posta por Meleto o censura pela introdução de novas divindades e, na argumentação esboçada, o réu defende-se de 'nãoateísmo', haveria ele realmente refutado a grafh em questão? Não seria legítimo considerar que sua defesa não se dirigiu propriamente à grafh' posta? Isto é, não teria ocorrido uma inversão na acusação durante a resposta apresentada por Sócrates? Desse modo não estaria infirmada a hipótese que sustenta ter sido a referida acusação completa e satisfatoriamente refutada?" Bem, apresentarse-á em dois planos a resposta à objeção levantada: primeiramente,

9 Infelizmente não é possível designar o nome do arguidor, uma vez que a memória nem sempre apresenta-se confiável. Todavia, trata-se de um docente que compôs a banca do processo seletivo de mestrado da Universidade Federal de Minas Gerais, em novembro de 2005, na qual o autor do texto apresentou-se como candidato. 
a partir de uma argumentação construída por Luc Brisson na introdução que antecede sua tradução da Apologia; e, em um segundo momento, emitir-se-á uma resposta própria deste texto.

Segundo Brisson (1997, p. 38-39), a primeira acusação - ouç mhn $\mathbf{h}$ pól iç nomízei qeoùç ou nomízon - apresenta uma extrema dificuldade em sua interpretação; gerada pela expressão où qeoùç nomízein, a qual mantém em sua designação uma ambigüidade. Para o especialista francês, a expressão "não reconhecer os deuses" pode significar tanto não reconhecer a existência de deuses, quanto não reconhecer as divindades que a pólis reconhece. Isso pode ser constatado através da invocação feita por Sócrates das duas possibilidades, na tentativa de tornar mais claro (safésteron) o significado da acusação de Meleto:

Então, Meleto, por esses mesmos deuses de que agora se trata, fala com mais clareza ainda, a mim e a estes senhores; não consigo entender se afirmas que ensino a crer na existência de certos deuses - nesse caso admito a existência de deuses, absolutamente não sou ateu, nem é esse o meu crime, se bem que não sejam os deuses do povo, mas outros, e por serem outros é que me processas - ou se afirmas que não creio mesmo em deus nenhum e ensino isso aos outros (Apol., 26b-d).

Desse modo, far-se-ia legítima a defesa de Sócrates, na medida em que, ao demonstrar não lhe fazer jus a acusação de ateísmo, estaria o filósofo defendendo-se exatamente da grafh contra ele apresentada. Isso ocorre porque a ambigüidade presente na expressão où qeoùç nomíze in foi desfeita pelo acusador, visto que Meleto - na qualidade de representante da grafh em questão optou por um dos sentidos implícitos no termo, a saber: "não reconhecimento da existência de deuses". Salienta Brisson que, seguindo esse raciocínio, a alusão feita à pólis e a referência ao nómoç indicariam a anuência de que um dever cívico estaria presente na acusação. Logo, Sócrates haveria sim se defendido satisfatoriamente das acusações impostas por Meleto.

Já o autor do presente texto desenvolveu, naquela

Educ. e Filos., Uberlândia, v. 21, n. 42, p. 119-153, jul./dez. 2007. 
oportunidade, outra argumentação à guisa de resposta. Sabe-se que o e l egcoç dialético, tal qual é preconizado por Sócrates, possui como regra constituinte que o interlocutor fale aquilo que pensa; condição imprescindível para que se alcance o téloç do método, isto é, a busca pela verdade. Pois, somente assim assegura-se versar a discussão sobre as próprias coisas e não apenas sobre seus nomes, ou seja, essa condição realiza o liame entre o indivíduo e suas palavras, de forma a garantir aos interlocutores que sua busca não se restrinja ao embate entre lógoiç. Eis uma caracterização de Platão sobre o fato:

É que me pareces desconhecer [Nícias dirige-se à Lisímaco] que quem for muito chegado a Sócrates (por convívio ou parentesco) e vier a falar com ele habitualmente, ainda que, de início, comece a discutir sobre algo diferente, inevitavelmente acabará por ser arrastado para uma conversa em círculo, até cair em dar resposta a perguntas sobre si próprio - como passa actualmente e como viveu a sua vida passada. Depois de aí ter caído, Sócrates não mais o largará antes de tudo ter posto à prova. É o bom e o bonito! Eu sou de sua intimidade e sei que é obrigatório sujeitar-se a ele nisto, e até sei muito bem que hei-de eu próprio a isso ser sujeito. Mas é um prazer, Lisímaco, conviver com ele, e confesso não ver mal nenhum em que nos lembrem que não temos agido ou não estamos a agir correctamente [...] eu bem sabia há muito que, na presença de Sócrates, não havíamos de ter uma conversa sobre os jovens, mas sobre nós próprios (Laques, 187e-188b; tradução de Francisco Oliveira).

Veja-se ainda essa outra passagem da Apologia, em que Sócrates vaticina aos que o condenaram:

Vós o fizestes supondo que vos livraríeis de dar boas contas de vossa vida; mas o resultado será inteiramente oposto, eu vo-lo asseguro. Serão mais numerosos os que vos pedirão contas; [...] Se imaginais que, matando homens, evitareis que 
alguém vos repreenda a má vida, estais enganados [...] (Apol., $39 \mathrm{c}-\mathrm{d})$.

Destarte, o método de Sócrates visa à busca moral no indivíduo, daquilo que ele pensa, daquilo que ele acredita ${ }^{10}$; pois somente assim pode o método ser fecundo e o reconhecimento da ignorância apresentar-se como um bem adquirido. Logo, Sócrates, ao refutar Meleto, interessa-se por aquilo que ele realmente pensa - daí seu intento em demonstrar que seu interlocutor não é sabedor naquilo que o acusa; de modo que pouco lhe importa que aquele mude ou reformule seu pensamento - pelo contrário, vê-se muitas vezes o filósofo incitar seus interlocutores a fazê-lo -, desde que ele diga a verdade acerca do que acredita. Portanto, é bem viável supor que, aos olhares de Platão e de Sócrates - por conseguinte, na perspectiva da Filosofia - , a refutação tenha-se manifestado completa e bem sucedida; e é esta razão que autoriza Sócrates a afirmar com convicção: "O que me vai condenar, se eu for condenado, não é Meleto, nem Ânito, mas a calúnia e o rancor de tanta gente" (Apol., 28a). Portanto, mediante os pressupostos do elegcoç socrático, não há nada de ilegítimo em afirmar que - aos olhares de Sócrates e de Platão - a acusação de Meleto é refutada, uma vez que a concepção filosófica daquele filho de Atenas leva-o a conduzir a discussão rumo às crenças internas de seu interlocutor, pois lhe importa muito menos o conteúdo grafado do que o que está moralmente presente nas acusações.

Portanto, uma vez refutada a objeção lançada, crê-se estar a poucas sílabas da argumentação que visa autenticar a hipótese proposta. Entrementes, faz-se necessário, anteriormente, traçar em poucas linhas um esboço do método dialético ${ }^{11}$.

10 "Em suma, o elenchos socrático se endereça de fato à vida de um indivíduo pelo viés de um exame de seu discurso" (BRISSON, 1997, p. 72).

${ }^{11} \mathrm{O}$ método dialético comporta mais de um sentido no pensamento platônico. Por essas razões, ter-se-á aqui em conta seu aspecto concernente à Apologia de Sócrates.

Educ. e Filos., Uberlândia, v. 21, n. 42, p. 119-153, jul./dez. 2007. 


\section{Um recuo dialético}

Platão define por dialética a arte de interrogar e responder (Crátilo, 390a). De fato, esse é um fator constante e essencial ao método em todos os seus momentos. As circunstâncias nas quais essa arte apresenta-se nos textos fazem-se muitas vezes semelhantes: instala-se um determinado programa de busca no diálogo, o qual deverá ser levado a cabo pelos protagonistas. Sócrates, na maior parte das vezes, toma as rédeas do percurso e submete os interlocutores a uma análise crítica de suas posições; as quais, mesmo mediante as reformulações que se apresentam, uma vez contraditas, quedam na aporia do tema proposto. Em suma, a dialética é o método característico da investigação filosófica socrática, a qual, para que se efetive com eficácia, deve respeitar algumas determinações que lhe são próprias.

O método dialético, diferentemente das argumentações sofísticas, não possui outro fim a não ser a busca pelo saber. Seu desenvolvimento, embora sujeito a todas as regressões que se façam necessárias, instaura-se totalmente no interior do diálogo, de modo a recusar qualquer interferência exterior em sua análise. Nesse viés, a forma de apresentação discursiva também se faz estabelecida: adota-se os curtos discursos (braculogía), em detrimento das longas proferições oratórias (makro l ogía); os discursos devem visar o estabelecimento do comum acordo (omo l ogía) entre os interlocutores, isto é, permitir que a tese sustentada por algum deles não se faça contraditória e possa ser por ambos admitida. Nesse sentido, a dialética se presta como um instrumento analítico, constante de perguntas e respostas, que visa checar o conhecimento, ou seja, estabelecer a verdade ou falsidade das opiniões dos interlocutores.

Nos moldes utilizados pelo Sócrates da Apologia, um procedimento faz-se caro ao método, a saber, o elenchos (e l egcoç). Como bem define Dorion (1997, p. 30): “O e legcoç é o teste, a prova que tem por fim verificar e colocar à luz se o indivíduo possui bem as qualidades (morais ou intelectuais) que ele pretende possuir". Faz-se proveitoso grifar na definição citada o caráter moral no qual se insere o procedimento "elênchtico", na medida 
em que o campo de reflexão filosófica de Sócrates - tal qual se apresenta na Apologia e em outros textos, denominados por alguns interpretes como diálogos de primeira época - evidencia-se com exclusividade em uma filosofia moral. Pois mesmo que se apresentem outros objetos, os únicos examinados pelo filósofo são os de caráter moral (VLASTOS, 1997, p. 127). Desse modo, então, é o el egcoç o método utilizado por Sócrates para mostrar, pela discussão dialogada entre duas pessoas, que a tese do interlocutor comporta uma contradição. Todavia, é mister, antes que se apresente a constituição lógica desse método, apresentar a origem histórica do termo ${ }^{12}$.

Chantraine (apud DORION, 1990, p. 312) atribui o primeiro uso de "elegcoç", conforme atesta o vocabulário homérico, no sentido expresso pelo substantivo "vergonha" ("honte"); posteriormente, no vocabulário iônico-ático, ter-se-ia o termo transformado e tomado o sentido de refutação - tal qual se encontra em Platão. Todavia, o recuo etimológico que Chantraine dá para o significado da palavra faz-se alvo de fortes críticas, em vista da imensa lacuna que separa o sentido homérico e aquele por ele designado como iônico-ático. Pois, pergunta-se: como teria o termo sofrido semelhante transmutação de significados? Um dos que lhe dirigiram essa crítica foi Lesher (apud DORION, 1990, p. 312), o qual, por sua vez, propôs uma nova análise para o termo "e l egcoç" - no intuito de demonstrar as nuances da evolução semântica que separa o uso feito por Homero daquele feito por Platão. Lesher também atribui ao primeiro significado do termo o sentido de vergonha. Nesse caso, Homero utilizar-se-ia do substantivo "tò e I egcoç" para designar o fracasso oriundo de determinada situação que apresentasse rivalidade, isto é, o malogro provindo de algum episódio em que fosse necessária a demonstração de valor - quer se tratasse de um combate ou de uma competição esportiva. Nesse sentido, o substantivo conota uma dimensão de revelação, na medida em que a vergonha é advinda do fracasso em um episódio que exigia a exibição de um carácter contrário ao do

\footnotetext{
${ }^{12}$ Para tanto, reproduzir-se-á a análise feita por Dorion (1990) sobre o termo.
}

Educ. e Filos., Uberlândia, v. 21, n. 42, p. 119-153, jul./dez. 2007. 
desfecho. A próxima transformação semântica do termo teria locus nos poemas de Píndaro, os quais, embora apresentem passagens que conservam a significação homérica - "tò e legcoç" para "vergonha"; e o verbo "elévcw" com o sentido de "provocar vergonha a" -, introduzem uma acepção nova para o termo, a saber: o sentido de teste, de prova, ou seja, daquilo que revela a verdadeira natureza ou valor de uma pessoa. Assim, Píndaro não apenas utiliza-se do substantivo "o e l egcoç" para denotar a prova, o teste, como também introduz o verbo correlato "exe légcw" na acepção de testar, provar (a verdadeira natureza de uma coisa). Nessa perspectiva, não se faz de difícil percepção o liame que une ambas acepções do termo. Enquanto o primeiro sentido caracterizado pelo gênero neutro "tò e l egcoç" - expressa a vergonha como resultado de uma prova em que deveria ter sido revelado um valor, o segundo - já com a utilização do gênero masculino "o e legcoç" - designa a prova ela mesma, o teste que revela a natureza de determinada coisa posta em xeque. Lesher identifica a próxima variação do termo em Heródoto, onde "el egcoç" seria usado, pela primeira vez, no sentido de refutar, a partir do qual teria chegado ao uso técnico promovido por Platão.

Louis-André Dorion, por sua vez, endereça a Lesher a mesma censura que esse havia dirigido a Chantraine: saltar etapas no tocante à evolução do termo "e l egcoç". Se assim procede, é porque não são de fácil apreensão as pegadas da mudança de sentido que separa Píndaro de Heródoto, nem é evidente como a partir do último toma o termo a acepção que se encontrará no autor dos diálogos socráticos. Primeiramente, Dorion demonstra que, após Píndaro, a próxima transformação significativa do termo toma lugar entre os trágicos, os quais, além do sentido de teste, prova (reveladora da verdadeira natureza das coisas), utilizam também o verbo "exe légcw" como sinônimo de confundir. Tais ocorrências evidenciar-se-iam em situações nas quais um indivíduo, por vias de interrogatório, desmascara (revela) a natureza perversa de um outro. Nesses moldes, a tradução do verbo pelo substantivo "interrogar" faz-se aceita; todavia, salienta o autor que: 
(...) não se trata somente de interrogar, mas, sobretudo, de interrogar com o fim de confundir, pois o questionador já está persuadido que seu interlocutor é culpado de um delito qualquer (crime, mentira, etc.) e, tomado dessa convicção, ele recorre ao interrogatório unicamente para fazer brilhar o delito à plena luz do dia (au grand jour) e assim revelar a culpabilidade da pessoa interrogada (DORION, 1990, p. 315).

Por outro lado, esse contexto não comporta a tradução de "exe l égcw" por "refutar" - conforme acreditou Lesher - mediante o caráter lógico e neutro da última concepção, uma vez que "exel égcw" está associado a uma dimensão da vergonha, visto que a pessoa confundida, por ter sido desmascarada, é necessariamente humilhada (eis o liame deste uso com as concepções anteriores). Dorion insiste nesse ponto, pois, segundo ele, essa é a ocorrência que se encontra em Heródoto (II, 115), justamente à qual Lesher havia atribuído o sentido de "refutar". Dorion demonstra (1990, p. 315-317) de que modo o último equivoca-se na tradução da passagem em questão, ignora um sentido já existente nas tragédias e atribui à passagem uma conotação inexistente até então. Assim, em vias de recapitulação, após as considerações de Dorion, a evolução etimológica do termo "e l egcoç" e dos derivados de mesma família encontram seus ápices, respectivamente, em: Homero, Píndaro e nos poetas trágicos - Heródoto é privado de significação nessa evolução. Todavia, como entre os trágicos e Platão o sentido do termo varia bastante, é mister que se busque o caminho percorrido pela transformação de "o elegcoç". Para Dorion, a próxima ocorrência de mudança etimológica do termo - e seus derivados - aparece no uso feito pelos oradores do V e IV séculos: Lísias, Antifonte, Demóstenes, Isócrates, Esquino, etc.

Enfim, chega-se ao ponto central da tese de Dorion, para quem a prática corrente dos tribunais - em sua utilização do "elegcoç" - marca significativamente a dialética socrática; uma vez que, considera ele, esse método efetiva-se através de uma "subversão do e legcoç jurídico". Logo, para demonstrar em que 
medida o procedimento de Sócrates desprende-se de semelhante prática, realiza o autor uma comparação entre esses procedimentos. Consoante Dorion, tanto o agwn quanto o procedimento dialético desenvolvem-se mediante a existência de duas pessoas que - em alguma perspectiva - se afrontam e se representam a si próprias. Não obstante, essa similitude extingue-se na medida em que a diferença que opõe os interlocutores do agwn apresenta-se absoluta e irrevogável, uma vez que em nenhum momento espera-se um acordo mútuo entre as partes. Pois, do mesmo modo que o acusador intenta provar a culpabilidade do acusado, este procura provar sua inocência demonstrando a falsidade da acusação. Assim, a pugna de ambos visa, unicamente, o convencimento de terceiros, a saber, dos juízes. Já no que tange aos interlocutores do procedimento dialético, não apenas o móvel que os dirige é distinto do a gwn, como também o é a relação estabelecida entre os debatedores. Pois, neste caso, procura-se o acordo mútuo, pelo fato de que a demonstração da inconsistência de um Iógoç manifesta-se como um passo para o reconhecimento da ignorância, e, como esse é um bem a ser alcançado na busca da verdade, também constitui um téloç do método. Assim, no contexto jurídico, "e légcw" designa: provar, estabelecer uma demonstração, convencer alguém de...13. É nesse sentido que o acusador busca provar a culpa do adversário, revelando a sua verdadeira natureza - eis o liame de significados com o uso precedente. Ora, o que significa essa demonstração de culpa, essa prova, tendo-se em mente haver no a gw $\mathbf{n}$ uma situação conflitante, cuja resolução somente pode ser obtida na vantagem de uma parte sobre a outra? Ou seja, como se realizava a prova (e l egcoç) em um tribunal de Atenas? Sabe-se que, na opinião da maior parte dos logógrafos, os melhores meios de prova

13 “'Convencer', neste caso bem preciso, não pode, com efeito, ser considerado como um sinônimo de 'persuadir'! Se $\mathbf{Y}$ convence $\mathbf{X}$ de assassinato, isto não significa, longe disto, que $\mathbf{Y}$ consegue fazer $\mathbf{X}$ admitir que ele é um assassino. Isso significa simplesmente que $\mathbf{Y}$ estabeleceu que $\mathbf{X}$ é um assassino, e para isso, pouco importa o assentimento ou não de $X^{\prime \prime}$ (DORION, 1990, p. 321). 
repousavam sobre o testemunho ${ }^{14}$ e sobre a verossimilhança (eikota). Contudo, ambos os meios faziam-se, no judiciário grego, anteriores ao agwn, isto é, a prova (e l egcoç) era obtida antes que se iniciasse o processo, sendo-lhe, assim, "exterior e anterior": anterior pelo momento de sua obtenção e exterior por não ser produzida dentro do curso do agwn ${ }^{15}$. Logo, em que medida pretende Dorion verificar alguma similitude entre o e l egcoç jurídico e o socrático - visto o primeiro ser obtido exteriormente ao processo em que se insere e, sobretudo, advir de origem discrepante da utilizada na dialética socrática? Seria, talvez, por conta de alguma ação no tribunal que fosse comum a ambos processos? Algum procedimento de inquirição entre acusador e acusado? Ora, conforme legado pelos textos dos oradores antigos, sabe-se que não era comum no tribunal o debate entre as partes, uma vez que, devido ao caráter de imprevisibilidade desse recurso, era mais seguro ater-se aos discursos preparados pelos logógrafos. Assim, a quase totalidade dos julgamentos fixava sua forma na seguinte ordenação: leitura das acusações pelo magistrado; discurso de acusação; discurso de defesa e votação - no caso de um agwn timhtóç, como ocorrido com Sócrates, estipulação das penalidades pelas partes e nova votação. Portanto, toda a cena decorria sem um debate direto entre as partes. Não obstante, consoante Lísias (apud DORION, 1990, p. 328), era permitido às partes

\footnotetext{
${ }^{14} \mathrm{O}$ e l egcoç mediante o testemunho (martúreç) era considerado como o melhor (leia-se: mais convincente) método. Mas, o que tornava esse recurso confiável? Havia na legislação grega, como nos dias de hoje, penas aplicadas ao perjúrio; contudo, os fatores que denotavam credibilidade a esse recurso são outros. Bem, tratando-se de um homem livre, sua própria condição parece denotar sua credibilidade. Todavia, no caso de um escravo ser apresentado como martúreç, a garantia de seu discurso era obtida mediante sua "submissão à questão" (twn dè basanisqéntwn); isto é, por vias da tortura (basánwn). E como o estabelecimento da validade dos martúreç era concedida à parte adversária, à qual competia a extração das respostas, esse recurso era considerado o melhor meio para o elegcoç (DORION, 1990, p. 323 et seq.).

${ }^{15} \mathrm{O}$ e l egcoç socrático, diferentemente, baseia-se exclusivamente no pensamento do interlocutor, isto é, exclusivamente na interioridade do procedimento.
}

Educ. e Filos., Uberlândia, v. 21, n. 42, p. 119-153, jul./dez. 2007. 
interrogarem-se no interior do agwn; embora esse recurso denominado de "erwqhsiç" - conforme já explicitado, muito raramente fosse utilizado. Mas, atente-se, ó estimado leitor, a fim de que não dê vazão a conclusões precipitadas. Pois, embora seja atestada a existência da erwqhsiç, é preciso verificar que semelhante procedimento não constitui parte do e legcoç jurídico, uma vez que, por um lado, neste contexto o termo denota a prova dada para comprovar uma causa - a qual é, exclusivamente, obtida anteriormente ao início do agwn -, por outro lado, o recurso à erwqhsiç não constitui meio para provar a culpabilidade ou a inocência de alguém. Portanto, esse procedimento é estranho ao el egcoç jurídico. Logo, consoante Dorion, a grande inovação realizada por Sócrates foi ligar o e l egcoç à erwqhsiç, de maneira que esta configure o único meio de alcançar àquele.

Vê-se a que ponto a erwqhsiç toma aqui, na Apologia, uma importância nova e capital. Enquanto que os logógrafos nunca haviam apresentado esse procedimento como um meio eficaz de obter uma prova, a erwqhsiç torna-se, com Sócrates, o único meio de obter um elegcoç verdadeiro, uma prova verdadeiramente digna desse nome. Entre os oradores, o essencial da prova repousava sobre os testemunhos [...] Medese a distância que separa o elenchos da Apologia daquele encontrado nos logógrafos. O elenchos praticado por Sócrates não é exterior ao processo, nem estranho a ele, uma vez que, sendo doravante associado ao procedimento da erwqhsiç, ele jorra do seio mesmo do afrontamento verbal que opõe os dois adversários. O elenchos da Apologia é imanente ao agwn (sic) e não mais exterior a ele (DORION, 1990, p. 339-340).

Nesse sentido, o termo "e l egcoç" assume, novamente, outra significação ${ }^{16}$; dessa vez em um sentido mais técnico, como um

${ }^{16}$ Entrementes, sem perder o sentido antigo de prova reveladora do valor de um homem (BRISSON, 1997, p. 72). 
método cujo té loç mira à verdade. Eis qual seria a dívida da Filosofia para com o sistema judiciário ${ }^{17}$.

Neste ponto, após esse mergulho na origem histórica do "elegcoç", não menos importante seria um breve exame da forma lógica constituinte do método - a fim de se recuperar o fôlego e dar cabo da travessia. A forma na qual o e l egcoç efetiva-se consiste na demonstração de que conseqüências retiradas de uma crença, outrora aceita pelo interlocutor, são contraditórias a outras opiniões por ele admitidas ${ }^{18}$. Para ressaltar as contradições na tese dos interlocutores, Sócrates utiliza dois tipos de raciocínios: o silogístico, que consiste em demonstrar que a negação de sua tese advém de conseqüências retiradas de um subconjunto de suas próprias crenças; e o epagógico ${ }^{19}$, que consiste em demonstrar por comparação, através de analogias, que a tese sustentada comporta contradições. Todavia, o recurso ao el egcoç somente permite a Sócrates identificar contradições na tese do interlocutor que a levem a ser descartadas; isto é, não se pode avançar rumo a uma definição procurada a partir de seu método, o qual se limita em explanar a ignorância do interlocutor sobre o assunto - o que por si só constitui um valor inestimável, na medida em que atua como um procedimento propedêutico para que o interlocutor se volte à busca da sabedoria. Assim, quando pergunta ti esti $X$ ? - em que $X$ representa uma virtude determinada -, Sócrates não deseja uma

17 "A dívida da dialética para com o uso dos tribunais situar-se-ia então neste empréstimo da erwqhsiç; por outro lado, sua profunda originalidade além disso terá consistido em fazer da erwqhsiç o meio por excelência da produção de um elenchos" (DORION, 1990, p. 340).

${ }^{18}$ Nesse sentido, a concordância do interlocutor, com os procedimentos metodológicos, faz-se estritamente necessária, uma vez que a não aceitação de uma tese pelo interlocutor impede todo o desenvolvimento do raciocínio.

${ }^{19}$ Muitas vezes identifica-se essa forma como um raciocínio por indução. Todavia, Vlastos (1994 apud DORION, 1997, p. 11, n. 7) ressalta a incompatibilidade entre a epagogé socrática e o que se entende por indução na lógica moderna, na medida em que na epagogé não se parte de afirmações particulares para corroborar uma afirmação universal, mas de subgrupos particulares que implicam em relações com outros subgrupos gerais, de modo que se identifiquem analogias entre eles.

Educ. e Filos., Uberlândia, v. 21, n. 42, p. 119-153, jul./dez. 2007. 
definição lexical, isto é, que lhe denominem o justo emprego do termo; nem deseja um exemplo ou ilustração concreta sobre o termo; mas sim, quer saber em que consiste o eidoç, a ousía da questão proposta, isto é, o que se faz essencial para que todas as coisas que apresentem a característica $X$ sejam X. Entrementes, o método por ele utilizado encontra seus limites na verificação de que a tese sustentada pelo interlocutor - anteriormente tomada por verdadeira - é falsa e, por conseguinte, deve ser rejeitada. Em nenhum momento permite que se possa ascender ao eidoç da questão. Por tal razão, a resposta para ti esti $\mathbf{X}$ apresenta-se sempre em forma de aporia.

Portanto, o elegcoç constitui o procedimento socrático por excelência para a efetivação da arte dialética. E sua realização pressupõe, ao menos, o diálogo entre dois interlocutores; o aceite de ambos dos termos da discussão, isto é, de que toda contradição estabelecida infirma a tese analisada; a harmonia entre o que o interlocutor pensa e o que profere como única garantia para que não se esteja a dizer algo sobre conceitos vazios, ou seja, para que se possa encontrar a verdade; e, sobretudo, pressupõe o recurso à erwqhsiç, procedimento sem o qual não pode ser aplicado o método e, conseqüentemente, sem o qual não pode haver Filosofia.

\section{Das acusações que permanecem}

Mediante o apresentado, maiores razões autorizam inferir que Sócrates não conseguiu refutar satisfatoriamente as acusações mais antigas a ele impostas, posto que, o contrário ocorre em relação às de Meleto. Posição freqüentemente enfatizada na Apologia pela voz do filósofo, por exemplo, ao afirmar que sua condenação não se deve a Meleto, "[...] mas a calúnia e o rancor de tanta gente, é o que perdeu muitos homens de bem e ainda os há de perder [...]" (Apol., 28b); e mais adiante: "[...] no tocante a Meleto, acho que fui absolvido" (Apol., 36a). Igualmente assinala Brisson (1997, p. 145):

Sócrates fundamentou sua defesa sobre uma refutação do tipo dialética e estima que a auto-contradição de Meleto 
constitui uma prova suficiente da inanidade de sua acusação. Eis aí algo inteiramente não usual no quadro de um processo. No limite, o processo poderia parar aí [refere-se à Apologia 28a, término da refutação de Meleto], pois Sócrates estima ter levado a cabo a prova de que Meleto contradissera-se sobre os dois pontos que compreendem o ato da acusação.

Ora, mas por quais razões Sócrates não refuta as acusações mais antigas? Será por descuido ou desleixo em relação à morte? Por não dedicar mais importância à última do que a um figo podre (Apol., 32 d)? Por incapacidade para fazê-lo? Por não desejar fazêlo? Sócrates não quis ou não pôde se defender? São essas tantas perguntas que podem ser sintetizadas, por um leitor mais acurado, na seguinte questão: quais as razões de Sócrates não ter se defendido satisfatoriamente das primeiras aleivosias?

Antes de dar cabo da questão, porém, urge trazer à tona outra pergunta, a saber: por qual motivo credita Sócrates um maior grau de temeridade às prwta kathgorhména (Apol., 18c)? A resposta é fornecida pelo próprio acusado, o qual afirma como razão de causa para seu temor, primeiramente, o fato de terem sido esses acusadores os responsáveis pela educação dos juízes presentes e, sobretudo, por não se poder designar nem quantitativamente nem qualitativamente os responsáveis por essas acusações. Por semelhante razão, “[...] nem sequer é possível citar aqui em juízo nenhum deles e refutá-lo [...] (oudè gár anabibásasqai oión $\mathbf{t}$ estìn autwn entauqoi oud elégxai oudéna)" (Apol., 18d). Ora, ora, ora... Eis a pista, ó amável leitor, que conduz à resposta da primeira questão levantada: não se pode nem anabibásasqai nem e légxai. De maneira que, continua Sócrates, "[...] o defensor é inevitavelmente obrigado a combater como que sombras, a replicar sem tréplica (te kaì elégcein mhdenòç apokrinoménou) (Apol., 18a)", isto é, a refutação deve ser realizada sem o recurso à erwqhsiç. Mas, sem o concurso desse procedimento, qual a possibilidade de aplicação da refutação, isto é, do elegcoç socrático? A reposta apresenta-se imediata e enfática: nenhuma!

Assim, a afirmação precedente - de que Sócrates não consegue

Educ. e Filos., Uberlândia, v. 21, n. 42, p. 119-153, jul./dez. 2007. 
refutar satisfatoriamente as acusações mais antigas - ganha corpo e solidez ao serem analisadas mediante a ótica do método filosófico, isto é, submetendo-as ao crivo do elegcoç. Pois, por um lado, o procedimento da erwqhsiç apresenta-se como condição indispensável para a prática do método filosófico, por outro, Sócrates encontra-se impossibilitado - mediante a indeterminação dos primeiros acusadores - de chamá-los a juízo (anabibásasqai), de lançar mão a semelhante recurso (e rwqhsiç) e, conseqüentemente, de refutá-los (e légxai). Portanto, não seria possível, durante o agwn, a refutação das prwta kathgorhména utilizando-se para tanto do método filosófico característico de Sócrates. Ao encontro dessa hipótese, atesta Dorion (1997, p. 336337):

O interesse dessa passagem [trata-se de Apologia 18a, pouco acima citada] é que o verbo e légcein é posto em relação com uma forma de exame e de interrogatório. Sócrates queixa-se, com efeito, de dever elégcein sem que ninguém possa responder-lhe. (...) Os antigos acusadores de Sócrates estão então, em virtude de sua ausência e de seu anonimato, ao abrigo da erwqhsiç e do elegcoç. Mas Meleto, que participa do processo, poderá ele se precaver? Nada é menos certo.

Isso explica a presença de tão inábeis argumentações no contexto da primeira defesa, onde se pode encontrar um Sócrates perdido, despojado de suas próprias armas em face de um inimigo sem rosto.

De fato, com Meleto a situação toma outro rumo. Sócrates não hesita em submetê-lo ao seu método - nem Platão em narrar o mestre a fazer uso, em tribunal, de procedimento tão pouco característico ao contexto - e em creditar como satisfeita sua refutação, isto é, atribuindo como causa de sua condenação, unicamente, as antigas diabolaí. A explicação para semelhante procedimento salta aos olhos: Sócrates preocupa-se, exclusivamente, com o valor moral da discussão, ou seja, seu único interesse versa pela busca da verdade; de maneira que, 
independentemente da validade de seu procedimento como meio de provar sua inocência, é à Filosofia que ele recorre e somente a ela atribui um caráter satisfatório para a refutação. Portanto, mais uma vez afirma-se: na perspectiva de Sócrates e Platão - leia-se: da Filosofia - a única refutação realizada satisfatoriamente, durante o processo, foi aquela imposta a Meleto; quanto às mais antigas, essas, além de não terem sido suficientemente refutadas, foram as causadoras da condenação do filósofo.

\section{Conclusão}

Manifesta-se patente em que medida a defesa esboçada por Sócrates não pôde ser in totum satisfatória - nem para ele, nem para Platão e nem mesmo para os leitores da Apologia, uma vez que Sócrates, perante as primeiras acusações, nada mais faz do que apresentar uma tentativa de indução quanto à não verossimilhança entre a acusação e sua conduta; esboçar uma distinção - via a ironia que lhe é característica - entre seu procedimento (leia-se: a Filosofia) e a prática sofística; e, por fim, remeter seu método a uma origem divina. Contudo, essas três ações não pareceram ser satisfatoriamente convincentes, na medida em que, uma tentativa de indução - tal qual a utilizada - não é o que se espera de um homem cuja vida versou em debates aprimoradíssimos e, a crer em Platão, utilizou-se de argumentações capazes de levar à aporia homens da magnitude de um Protágoras ou de um Górgias. Por outro lado, a tentativa de Sócrates em estabelecer os liames que separam a figura do filósofo daquela do sofista não se faz fecunda, uma vez que dificilmente um público não especializado - sobretudo, anterior ao pensamento de Platão e Aristóteles - poderia delimitar a linha divisória entre ambas as práticas. Por último, a remissão de sua conduta a uma origem divina - sobretudo, nos moldes em que foi feito - pouco lhe fornece estratégia de defesa, assim como, possivelmente, pode ter contribuído ainda mais para a hostilização de sua pessoa. Por fim, na busca de firmar a hipótese proposta, conta-se com o testemunho de ninguém menos do que o próprio Sócrates, o qual, durante toda

Educ. e Filos., Uberlândia, v. 21, n. 42, p. 119-153, jul./dez. 2007. 
a Apologia, credita sua condenação à impossibilidade de defesa perante as prwta kathgorhména.

Diferentemente do que sucede às primeiras aleivosias, Sócrates refuta uma a uma as acusações postas por Meleto, uma vez que, no tocante a essas, pôde o filósofo utilizar-se de sua maneira habitual de falar (entenda-se: refutar); isto é, pôde ele fazer uso do elegcoç e demonstrar que seu "interlocutor-acusador" encontrava-se em contradição. Em outras palavras: demonstrou que Meleto não é sabedor daquilo que o acusava, por conseguinte, que semelhantes acusações não se fundamentavam.

Nesse ínterim, fica patente que a ineficácia da defesa de Sócrates, mediante as primeiras acusações, deveu-se à impossibilidade de execução de seu método. O que é atestado pelo próprio filósofo, quando pontua como causa para creditar maior temeridade às antigas diabo laí o fato de não se poder delimitar seus acusadores, seja em nome ou em número; o que torna impossível convocá-los a juízo (anabibásasqai) e, por conseguinte, refutá-los (e légxai). Ou seja, semelhante refutação somente poderia ser realizada sem o concurso da erwqhsiç. Todavia, consoante Dorion, a grande inovação realizada por Sócrates - em relação à pratica jurídica - consiste na ligação do e legcoç à erwqhsiç e, por conseguinte, na atribuição de um status de valor de prova ao indissociável conjunto; de forma que esteja contido nesse método o único caminho para se alçar ao conhecimento verdadeiro. Isto é, a erwqhsiç constitui conditio sine qua non para a efetivação do e legcoç socrático, de maneira que sua ausência torna infecunda e impossibilita metodologicamente a refutação, por parte de Sócrates, das prwta kathgorhména.

Assim, Platão deixa claro, na redação da Apologia de Sócrates, a medida do alcance do el egcoç socrático, como as limitações que lhe são concernentes, de modo que, para uma leitura pautada na ótica filosófica, a atribuição da condenação às prwta kathgorhména apresenta-se evidente; pois essas habitam uma região imune ao método do filósofo. Por conseguinte, se Sócrates não hesita em submeter Meleto à prova, no que tange às outras 
acusações não era muito o que podia ser feito: com certeza, eralhe permitido recorrer aos testemunhos dos presentes e intentar uma espécie de indução que desse ao júri garantias de sua "boa índole"; era-lhe lícito ironizar o absurdo que o acometia ao ser vinculado ao rol de pensadores em questão; e era-lhe possível remeter seu método a uma origem divina, na esperança de aproximar sua prática insólita dos costumes vigentes. Somente não lhe era possível o uso de uma prática refutativa que, coincidentemente, convergia com a única que acreditava poder trazer aos presentes a verdade e proporcionar ao interlocutor o maior dos bens: o reconhecimento da própria ignorância.

Destarte, fica exposta e demonstrada a hipótese tética do presente estudo, a saber: Sócrates, tal qual o retrata Platão, encontra-se incapacitado de realizar a defesa de parte das acusações apresentadas na Apologia - mais precisamente, das mais antigas sendo que tal impossibilidade faz-se oriunda de limitações inerentes ao seu método filosófico.

\section{Referências}

CANTO-SPERBER, M. Le premier philosophe de la connaissance. Philosophie Grecque. Paris: PUF, 1997. p. 205-215.

DORION, L. A. La subversion de l'elenchos juridique dans l'Apologie de Socrate. La Revue Philosophique de Louvain, Louvain, v.88, n. 3, p. 311-344, Agosto, 1990.

MOSSÉ, C. Atenas: a História de uma Democracia. 2 ed. Tradução de João B. da Costa. Brasília: Editora Universidade de Brasília, 1982.

O Processo de Sócrates. Tradução de A. Marques. Rio de Janeiro: Jorge Zahar, 1990.

Politique et Société em Grèce ancienne: le modèle athénien. [s. 1.]: Aubier, 1995.

Educ. e Filos., Uberlândia, v. 21, n. 42, p. 119-153, jul./dez. 2007. 
PLATON. Oeuvres Complètes. Tradução e notas de L. Robin. Paris: Gallimard, 1950.

Defesa de Sócrates. Tradução de J. Bruna. São Paulo: Abril Cultural, 1972. (Os Pensadores).

Defensa de Sócrates. Texto anotado por Manuel FernándezGaliano. 2. ed. Madrid: Gredos, 1985.

Apologie de Socrate, Críton. Tradução, introdução e notas de Luc Brisson. Paris: Flammarion (G. F.), 1997.

Lachès, Euthyphron. Introdução, tradução e notas de LouisAndré Dorion. Paris: Flammarion, 1997.

Laques. Tradução, introdução e notas por F. Oliveira. Lisboa: Edições 70, [19-].

VLASTOS, G. Socratic Studies. Cambridge: Cambridge University Press, 1994.

Sócrates. In: CANTO-SPEBER. Philosophie Grecque. Paris: PUF, 1997. p. 123-144.

Data de Registro 28/11/06

Data de Aceite 19/03/06 
